\title{
DINAMIKA DERAJAT PERSAINGAN INDUSTRI PERBANKAN INDONESIA
}

\author{
Idah Zuhroh \\ Fakultas Ekonomi dan Bisnis Universitas Muhammadiyah Malang \\ E-mail : zuhrohida@yahoo.co.id
}

\begin{abstract}
This study aims to investigate the dynamics of the degree of competition in the banking industry in Indonesia, especially in the banking consolidation period ( 2000 2008) is measured from the concentration ratio (CR 8) and Learner index. Samples were grouped into eight largest bank size (CR8) and outside CR8. The findings indicate that during the consolidation period (2000 -2006), concentration ratio tend to decrease of $70 \%$ towards $62 \%$. But after periode 2006, concentration index is constan. Degree of competition by largest bank size (CR8) indicated by an Learner index greater and is likely to increase rather than smaller bank size (outside CR 8). This gives a signal that largest bank size have more market power to direct output prices ( credit) above marginal cost compared to the group of banks outside of CR 8 .
\end{abstract}

Keywords: Banking industry, The degree of competition, Concentration index, Learner and Market power

\begin{abstract}
Abstrak
Penelitian ini bertujuan untuk menginvestigasi dinamika derajad persaingan industri Perbankan di Indonesia khususnya pada periode konsolidasi perbankan (20002008) yang diukur dari ratio konsentrasi (CR 8) dan indeks Learner. Sampel dikelompokkan ke dalam 8 bank terbesar (CR8) dan di luar CR8 . Hasil temuan menunjukkan bahwa selama masa konsolidasi ( tahun 2000 -2006), terjadi penurunan ratio konsentrasi dari 70\% menuju 62\%. Namun setelah tahun 2006 indeks konsentrasi cenderung konstan. Derajad persaingan oleh bank skala besar ditunjukkan oleh indeks learner lebih besar dan cenderung meningkat dibanding bank yang berskala lebih kecil ( di luar CR 8). Hal ini memberikan signal bahwa bank berskala besar lebih mempunyai kuasa pasar untuk menetapkan harga output kredit di atas Marginal Cost dibanding kelompok bank diluar CR 8.
\end{abstract}

Kata kunci: Industri perbankan, Derajad persaingan, Indek konsentrasi, Indeks learner dan Kuasa pasar

Dua dekade ini, persaingan industriperbankan mendapat perhatian dalam literatur perbankan di Indonesia khususnya setelah terjadi goncangan sistemkeuangan dipertengahan tahun 1998. Jika di awal perkembangan Industri Perbankan, otoritas meyakini bahwa persaingan sebagaimana yang diyakini oleh pemahaman klasik memberikan dampak po- sitif terhadap kinerja industri maupun konsumen (Bain, 1951 yang diilhami pemikiran Chamberlain, 1938) tidak sepenuhnya benar dalam industri perbankan.

Kerasnya persaingan dalam industri perbankan tidak selalu berdampak perluasan ketersediaan output maupun rendahnya tingkat bunga kredit di masyarakat namun 
dapat terjadi sebaliknya yaitu instabilitas. Kondisi inilah yang dihadapi industriPerbankan Indonesia, ketika terjadi liberalisasi perbankan (1986 -1997) persaingan telah meningkatkan risiko bank. Kejadian serupa sesuai temuan oleh Vives (2010) yang meneliti industri perbankan Eropa dan Amerika bahwa terjadi trade off antara liberalisasi dengan stabilitas perbankan. Menurutnya diperlukan regulasi yang tepat agar tidak sampai dampak positif persaingan mengorbankan stabilitas sistem keuangan.

Hubungan antara derajat persaingan dengan stabilitas keuangan juga telah dikaji oleh Rauldan Jesus (2010) pada perbankan Meksiko. Mereka membuktikan bahwa upaya regulasi konsolidasiperbankan dengan tujuan mengurangi kerasnya persaingan berdampak kepada meningkatnya stabilitas keuangan di negara tersebut. Temuannya memperkuat dukungan terhadap bukti dampak negatif kerasnya persaingan di sektor perbankan terhadap stabilitas keuangan diantaranya oleh Marcus (1984), Keeley (1990), Carletti dan Hartman (2003).,

Toleransi terhadap struktur pasar tidak bersaing sempurna atau cenderung oligopolis dapatlah dimaklumi.

Terdapat beberapa perbedaan karakteristik mendasar antara sektor keuangan perbankan dengan sektor manufaktur di antaranya: Kebutuhan modal yang sangat besar, struktur modal yang berat kepada hutang (baca dana pihak ketiga), adanya gap antara maturitas sisi aset dan liabilitas serta mudahnya terjadi efek penularan. Keempatnya secara akumulatif akan mendorong meningkatnya risiko bank sehingga industri perbankan membutuhkan pengaturan yang relatif ketat dibanding industri manufaktur.

Keberadaan bank yang mendominasi sistem keuangan di Indonesia menempatkan peran otoritas untuk dapat mengawasi dan memberikan iklimyang mendukung pertumbuhan bank yang sehat dan kuat. Konsolidasi yang ditujukan untuk menurunkan tingkat persaingan diharapkan mampu menurunkan tingkat risiko atau meningkatkan stabilitas bank.

Kepentingan stabilitas bertolak belakang dengan upaya mendorong dampak positif persaingan. Dikhawatirkan ketika terjadi konsolidasi perbankan akan meningkatkan derajat monopoli oleh bank yang berdampak negatif menguatnya kuasa pasar. de Rozas (2007) menyatakan bahwa kuasa pasar menunjukkan kemampuan perusahaan dalam pengendalian harga, sementara dalam persaingan harga tercipta karena kekuatan permintaan dan penawaran relatif sama sehingga setiap pihak tidak ada yang mampu mengendalikan harga kecuali hanya sebagai pengambil harga (price taker).

Merujuk kepada pengertian di atas terkait dengan sektor perbankan adalah mereka yang mempunyai kuasa pasar akan berupaya mempertahankan tingkat bunga kredit tinggidengan cara membatasi penawaran kredit ke masyarakat. Keuntungan akan diperoleh bank yang bertindak oligopolis melalui pengendalian bunga kredit karena mampu bertindak sebagai price maker di pasar keuangan perbankan.

Merujuk kepada kedua kelompok pandangan yang ada terkait pro-kontra persaingan maka dibutuhkan regulasi yang tepat oleh otoritas yang mencari titik temu antara upaya konsolidasi untuk tujuan stabilisasi sistem keuangan di satu sisi dan mendorong persaingan di sisi yang lain. Sejauh mana tingkat persaingan harus ditolerir untuk tidak mengganggu stabilitas sistem keuangan.

Penelitian ini mengkaji bagaimana dinamika persaingan industri perbankan di Indonesia di tengah langkah konsolidasi perbankan oleh otoritas baik secara struktur mau- 
pun perilaku bank dalam penetapan harga. Penelitian sejenis telah dilakukan di antaranyaAthoillah (2010) dan Widyastuti dan Budi (2013).

Athoillah (2010) menggunakan 10 sampel bank terbesar berdasar aset di Indonesia (periode 2002-2007) melalui pengujian indeks Panzar Rosse(Statistik H) yang menyimpulkan bahwa struktur pasar perbankan adalah monopolistik. Elastisitas hargainput positif menunjukkan bahwa kenaikan harga input tidak menurunkan pendapatan bank dalam arti bank masih menikmatikeuntungan meski harus menanggung kenaikan biaya. Pengendalian harga output disinyalir mampu mengkompensasi kenaikan biaya melalui pembatasan output kredit. Pada penelitian ini belum dipilah apakah bank yang berada di luar top ten (10 besar aset) juga memiliki statistik H yang sama, demikian pula bagaimana kecenderungan perkembangan persaingan dari waktu selama periode pengamatan belum dikaji.

Sementara kesimpulan tentang struktur pasar perbankan Indonesia yang bersifat monopolistis juga diperkuat oleh temuan Widyastuti dan Budi (2013) yang mengelompokkan industri perbankan ke dalam Bank Pemerintah, Bank Devisa, Non Devisa, Bank Pembangunan Daerah, Bank Join Ventura, Bank Asing serta seluruh Bank. Mereka menggunakan indeks yang sama sebagaimana peneliti sebelumnya namun lebih mengembangkan kepada berbagai ukuran tentang pendapatan bank serta dalam variabel penjelas di luar harga input juga diperluas untuk menghasilkan model yang relatif tepat. Berbagai definisi input output sektor perbankan telah digunakan dan hasilnya mendukung temuan sebelumnya seperti Claessen dan Laeven (2004) serta Athoillah (2010).

Kesimpulan menarik dinyatakan bahwa ada kecenderungan semakin menurunnya persaingan untuk semua jenis bank ke- cuali Bank Pembangunan Daerah yang cenderung konstan. Kontribusi terbesar tingginya derajat monopoli sehingga mengarah kepada struktur monopolistik bahkan oligopolis adalahrendahnya persainganolehbank asing, Bank Pembangunan Daerah dan Bank Devisa.

Perbedaan utama penelitian ini dari kedua penelitian yang telah diuraikan sebelumnya adalah upaya untuk membandingkan derajat persaingan antara kelompok perbankan yang tergolong dalam penguasaan aset tertinggi(CR8) dengan kelompok di luar CR8. Merujuk pada metodologi yang dikembangkan olehWidyastutidan Budi(2013) yang memperhatikan kecenderungan derajat persaingan di setiap kelompok Bank, penelitian menggunakan pendekatan analisis yang berbeda dalam menilai perilaku kompetitifnya yaitu indeks learner seperti halnya yang telah digunakan oleh beberapa peneliti di antaranya Sanya dan Mathew (2012) dan Iveta (2012).

Setidaknya ada dua keunggulan indeks Learner sebagai pengukur derajat persaingan dibanding indeks Panzar Rosse. Pertama tidak menuntut persyaratan model equilibrium serta memberikan derajad bebas yang lebih banyak mengingat model Panzar Rosse harus melibatkan variabel kontrol yang lebihselain penjelas persaingan (Athoillah, 2010). Kedua, derajat persaingan ditunjukkan oleh perilaku bank dalam pengendalian harga dapat diketahui mengingat indeks tersebut melihat posisi perbandingan antara harga output dengan marginal cost (Casu dan Girardone, 2009; serta Berger et al., 2009).

Penelitian ini selain merupakan pengujian kembali untuk menguatkan kesimpulan dari hasil penelitian sebelumnya juga ingin mengukur seberapa besar kemampuan perbankan dalam pengendalian harga kredit terutama jika dibandingkan antara bank berskala besar dengan bank berskala lebih kecil. 


\section{Metode Penelitian}

Penelitian ini melibatkan22 Sampel Perbankan yang go public di Bursa Efek Indonesia yang diamati daritahun 2000.1-2008.4. Sampel dikelompokkan berdasar penguasaan aset untuk 8 bank terbesar (CR 8) dan sisanya 14 bank di kelompokkan di luar CR 8. Data-data yang dibutuhkan dalam penelitian dihimpun dari statistik Bank Indonesia maupun PublikasiLaporan Kinerja Bank yang diterbitkan oleh Bursa Efek Indonesia maupun diunduh dari: www.bi.go.id. Laporan kinerja tersebut berupa laporan RugiLaba dan neraca.

Beberapa data input output yang digunakan untuk kepentingan analisis adalah: total biaya bank (TC) adalah seluruh beban perusahaan perbankan yang terdiri atas beban personal, beban administrasi lain, pembayaran bunga dan non bunga. Harga input labor $\left(\mathrm{W}_{1}\right)$ diproksi dengan rasio beban personal terhadap earning asset, harga modal fisik $\left(\mathrm{W}_{2}\right)$ merupakan rasio beban depresiasi terhadap aktiva tetap, $\mathrm{W}_{3}$ adalah harga dana DPK diproksi dengan rasio beban bunga terhadap dana pihak ketiga. Sementara output (Y) adalah kredit. Data-data lain juga digunakan dalamrangka mendukung diskripsi hasil penelitian di antaranya data nilai aset, harga kredit dan tingkat keuntungan bank.

Metode analisis merujuk pada tujuan penelitian yaitu: 1 . mengukur perkembangan derajat persaingan perbankan dan 2. Membandingkan kuasa pasar yang ditunjukkan oleh derajat persaingan yang dihadapi kedua kelompok bank terutama dari kemampuannya dalam pengendalian harga kredit. Terdapat lima langkah analisis untuk menjawab tujuan penelitian adalah sebagai berikut:

Pertama: untukmengetahuistruktur persaingan digunakan indeks konsentrasi (CR dimulai CR 5 sampai CR 10). Indeks konsentrasi tersebut mengukur pangsa pasar perusahaan terbesar yang diurutkan berdasarkan aset terbesar sampai ke bawah dalamindustriperbankan. Ukuran ini hanya melihat kepada seberapa besar penguasaan pangsa pasar oleh perusahaan terbesar sehingga dikhawatirkan memunculkan tindakan kolusif. Selanjutnya pengelompokan konsentrasi pasar ditujukan untuk menganalisis perbandingan perilaku bank dalam penentuan harga kredit baik untuk menjawab kedua tujuan penelitian.

Kedua: menyusun model fungsi dualitas minimisasi biaya dalam persamaan frontier stokastik Cobb-Douglas mengikuti Aigner et al. (1977). Sementara definisi input output sektor perbankan yang merupakan variabel penjelas merujuk argumentasi Sealey dan Lindlley (1997).

$\ln \mathrm{TC}=\beta_{0}+\beta_{1} \ln \mathrm{W}_{1}+\beta_{2} \ln \mathrm{W}_{2}+\beta_{3} \ln$
$\mathrm{W}_{3}+\beta_{4} \ln \mathrm{Y}+e i \ldots \ldots .(1)$

Koefisien $\beta_{1} \beta_{2}$ dan $\beta_{3}$ dalampersamaan (1) menunjukkan elastisitas harga input secara berturutan untuk Dana Pihak Ketiga (DPK), labor dan capital. Sementara $\beta_{4}$ merupakan elastisitas kredit terhadap biaya bank. Persamaan dualitas biaya diestimasi dengan menggunakan regresi data panel yang melibatkan 22 bank dengan periode pengamatan 2000.1-2008.4. Beberapa kelebihan regresi panel di antaranya: memperbesar ukuran sampel, sangat baik untuk mempelajari perilaku data secara dinamis (Gujarati, 2003 p. 652) meski model menjadi lebih kompleks (Nachrowi dan Hardius: 2006, hal: 310). Analisis frontier minimisasi biaya menggunakan software Frontier 4.0 yang didesain oleh Coelli, T. J (1996a).

Ketiga, mencari fungsi Marginal Cost berdasar derivasi hasil estimasi fungsi dualitas biaya pada persamaan (1) yaitu:

$\mathrm{MC}$ it $=\mathrm{TC}$ it $/ \mathrm{Y}$ it $\left(\beta_{4}\right)$ 
Berdasar hasil persamaan (2), akan diketahui bagaimana MC setiap bank di setiap periode, untuk kemudian diambil nilai rata-rata per tahun dan dikelompokkan berdasar skala usaha untuk dianalisis lebih lanjut terkait dengan dinamika derajat persaingan yang dihadapinya.

Keempat, indeks Learner ditentukan dengan menggunakan formulasi yang digagas oleh Learner (1934) dalam paper yang berjudul " the Concept of Monopoly and the Measurement of Monopoly" di mana akan diukur penyimpangan antara harga output $(\mathrm{P})$ dengan Marginal Cost (MC) (Elzinga, K.G and David, 2012).

$$
\mathrm{L}=(\mathrm{P}-\mathrm{MC}) / \mathrm{P} .
$$

Indeks Learner akan berada dalam rentang 0 dan 1 . Semakin mendekati 0 semakin rendah kuasa pasar bank dalam pengendalian harga atau semakin berada dalam posisi price taker (pasar persaingan). Sebaliknya indeks Learner mendekati 1 semakin kuat kuasa pasar atau menuju persaingan yang longgar (rendah) menuju monopolistis, oligopolis bahkan jika sama dengan 1 bank dapat bertindak sebagai price maker sepenuhnya atau berstruktur monopoli.

Terakhir, dinamika persaingan akan diuraikan berdasar pengelompokan CR 8 dan non CR 8 untuk diperbandingkan dengan mengambil data rata-rata pertahun.

\section{Hasil Penelitian dan Pembahasan}

Salah satu ciri industri berada dalam posisi yang ketat adalah banyaknya jumlah perusahaan yang berpartisipasi di pasar. Penguatan sektor perbaikan pasca krisis dilakukan oleh Bank Indonesia melalui upaya membatasi peluang entry bagi bank-bank baru, salah satunya adalah peningkatan ketentuan modal minimal. Sebagai akibatnya, pemenuhan persyaratan tersebut menuntut bankbank harus mencari sumber permodalan ba- ik dengan menambahmodal disetor oleh pemilik, melakukan divestai saham, dorongan terhadap merger atau harus keluar dari industri. Berkaitan dengan hal tersebut jumlah perkembangan bank secara perlahan mengalami penurunan. Sebagai gambaran jika di tahun 2002, jumlah bank masih 145, di tahun 2008 tersisa 124 bank dan diperkirakan jumlah ini mengalami penurunan kembali seiring rencana beberapa bank untuk merger.

Ditinjau dari jumlah bank yang masih berada di atas angka 100, dapat dikatakan bahwa bank-bank di Indonesia berada dalam posisi persaingan yang mendekati sempurna. Namun, kesimpulan tersebut harus didukung oleh derajat konsentrasi penguasaan pasar yang relatif merata. Kondisi ini mengisyaratkan bahwa dalam posisikekuatan yang sama, setiap pelaku pasar akan berupaya meraih segmen pasarnya dengan tidak berkesempatan memperoleh margin yang berlebihan. Ketika sebuah bank memberlakukan harga di atas pesaing, maka nasabah akan mudah berpindah kepada bank-bank lain yang menawarkan harga di bawah bank yang bersangkutan. Sebaliknya, bank tidak akan mampu menawarkan harga dibawahindustri, mengingat margin yang diperoleh hanyalah laba normal. Akibatnya bank-bank dituntut untuk bekerja pada biaya rata-rata minimum, agar tidak dipaksa keluar oleh industri (Eisenbeis, et al., 1999).

Fakta yang terjadi dalam industri perbankan di Indonesia, tidak seperti yang diharapkan oleh neo klasik tentang ciri persaingan sempurna. Banyaknya bank tidak diikutioleh distribusi penguasaan pasar secara merata. Jumlah bank yang mencapai angka 124 , hanya terkonsentrasikepada 8 bank terbesar (CR 8), di mana bank-bank tersebut mampu menguasai pangsa pasar baik dari aspek kredit, Dana Pihak Ketiga (DPK) dan asset lebih dari 60\% (lihat Tabel 4.1). Hal 
ini dapat diartikan bahwa 114 bank lain hanya menguasai pangsa pasar $40 \%$ atau jika dirata-rata, setiap bank menguasai pangsa pasar tidak lebih dari $4 \%$, atau struktur pasar perbankan Indonesia mengisyaratkan bersifat oligopoli.

Kecenderungan sifat oligopoli dalam struktur pasar perbankan di Indonesia, diperkuat pula bahwa 10 bank terbesar dalam penguasaan pasar di atas memilih distribusi yang sangat timpang dimana pangsa 5\%-10\% hanya dikuasai oleh 5 bank dalam CR10, sementara 5 bank yang lain hanya $2 \%-3 \%$ kelima bank dengan penguasaan pangsa pasar tersebut adalah: Bank Mandiri, Bank Rakyat Indonesia, Bank Negara Indonesia, Bank Central Asia dan Bank Danamon. Lima bank yang disebutkan terakhir (masuk dalam CR5) menguasai $44 \%$ pangsa pasar industri. Dapat diperhatikan pula, penurunan ratio konsentrasi CR10 dari waktu ke waktu sangat lamban, bahkan dapat dikatakan stagnan pada kisaran ratio $60 \%$.

Struktur pasar oligopoli, akan mendorong perilaku bank dalam penetapan harga kredit bertahan pada tingkat bunga tinggi. Sementara bank-bank kecil akan cenderung mengikuti kebijakan bank-bank yang bertindak sebagai pemimpin harga. Sebaliknya dari aspek harga DPK, bank besarpun akan bertindak sebagai oligopolis yang mampu mengendalikannya. Sebagai contoh ketika BI rate sebagai indikator signal bunga mengalami penurunan, bank-bank besar segera menurunkan bunga simpanan, namun tegar dalam bunga kredit. Industri perbankan di tahun 2007-2008 masih bertahan dengan kredit ketat dan bunga kredit tinggi.

Keyakinan tentang dampak negatif pasar terkonsentrasi tampaknya terbukti pada pasar perbankan Indonesia. Konsolidasi bank telah mendorong penetapan margin tinggi, tanpa ada kekhawatiran diri bank besar untuk ditinggalkankreditur. Sebagai gambaran bagaimana perkembangan margin yang diperoleh industri dapat diperhatikan pada tabel 2.

Perolehan margin industri perbankan Indonesia semakin tinggi dari semula (periode 2002) hanya $5.65 \%$ menjadi $8 \%$ di tahun 2008. Besarnya perolehan margin menunjukkan bah-

Tabel 1. Rasio Konsentrasi (CR8) Industri Perbankan

\begin{tabular}{cccc}
\hline \multirow{2}{*}{ Periode } & Kredit & Pangsa Pasar $(\%)$ & DPK \\
\hline 2002 & 61.84 & 71.90 & 70.95 \\
2003 & 62.57 & 69.91 & 70.09 \\
2004 & 63.03 & 67.89 & 66.50 \\
2005 & 61.95 & 65.47 & 63.85 \\
2006 & 61.36 & 64.00 & 61.82 \\
2007 & 60.72 & 64.15 & 62.50 \\
2008 & 60.76 & 65.03 & 62.22 \\
\hline
\end{tabular}

Sumber: Statistik Bank Indonesia, diolah

Tabel 2. Net Interest Margin (NIM) Industri Perbankan

\begin{tabular}{cccc}
\hline Periode & NIM dalam \% & Periode & Nim dalam \% \\
\hline 2002 & 5.65 & 2006 & 7.35 \\
2003 & 7.22 & 2007 & 7.17 \\
2004 & 6.29 & 2008 & 8.00 \\
2005 & 6.20 & & \\
\hline
\end{tabular}

Sumber: Direktori Bank Indonesia 
wa perilaku oligopoli semakin kuat. Diakui bahwa hubungan antara derajat konsentrasi dengan perilaku bank dalam mengeksploitasi kuasa pasar masih belum membutuhkan pengujian secara statistik. Namun, secara sepintas dapat diperhatikan ada hubungan yang positif antara derajat konsentrasi dengan kinerja bank yang dalam hal ini tingginya perolehan margin (NIM).

Kinerja dari aspek NIM sengaja digunakan sebagai indikator kerja bank, mengingat ratio tersebut sekaligus mampu memberikan gambaran perilaku bank dalam penetapan harga. NIM yang tinggi menunjukkan bahwa penghargaan atas aktiva produktif bank masih tinggi. Hal ini mengartikan bahwa bank menjual aktiva produktif yang dinilai dari tingginya bunga tidak menghadapi kendala dalam penyaluran kreditnya di mana kekuatan penawaran (bank) masih jauh lebih tinggi dibanding kekuatan permintaan kredit. Akibatnya, kreditur yang direalisasi kreditnya harus pasrah kepada bank dengan ketentuan bunga yang diberlakukan bank tanpa adanya kekuatan posisi tawar. Kuatnya daya tawar bank dalam output tidak terlepas pula adanya ketidakseimbangan antara pertumbuhan DPK yang jauh lebih rendah dengan kebutuhan kredit selama periode pengamatan.

Daya tawar bank yang kuat ditunjukkan oleh semakin selektifnya bank dalam pe- nyaluran kredit. Banyaknya kredit yang berkualitas buruk akibat kerasnya persaingan sebelum krisis masih menyisakan kredit buruk dalam tahap penyelesaian di tahun-tahun pengamatan. Bank masih enggan menyalurkan pembiayaan, terbukti Loan to Deposit Ratio $(L D R)$ jauh dari angka maksimal yang ditetapkan oleh Bank Indonesia yakni 110\%. Ini dapat diartikan bahwa selama waktu pengamatan, industri perbankan tidak menjalankan peran intermediasi secara optimal. Bahkan ada kecenderungan bank menghasilkan keuntungan bukan dari peran utamanya dalam penyaluran kredit, namun telah mengalihkannya kepada aktiva produktif lain yakni penempatan pada secondary reserve berupa surat berharga yang tidak beresiko ataupun memperdagangkannyadalam Pasar Uang Antar Bank (PUAB). Bunga yang diperoleh bank selain dengan mempertahankan bunga kredit tinggi pada korporasi yang dianggap konsisten berkualitas baik.

Tabel3 menunjukkan pemanfaatan DPK kepada output kredit oleh industri perbankan secara perlahan mengalami kenaikan. Bank dengan penyaluran kredit terendah meningkatkan LDR dari $18.96 \%$ di tahun 2002 menjadi $52.36 \%$. sementara bank yang berani mengekspansi output kredit telah sedikit melampaui batas maksimal LDR yakni dari semula $96.38 \%$ tahun 2002 menjadi $112.6 \%$ di tahun 2008.

Tabel 3. Pemanfaatan DPK kepada Output Kredit (LDR)

\begin{tabular}{cccc}
\hline Periode & Minimum & Maksimum & Rata-rata \\
\hline 2002 & 18.96 & 96.38 & 52.61 \\
2003 & 20.55 & 96.37 & 56.55 \\
2004 & 22.15 & 95.89 & 60.22 \\
2005 & 31.37 & 90.90 & 63.81 \\
2006 & 38.31 & 93.50 & 6.15 \\
2007 & 40.71 & 98.22 & 71.03 \\
2008 & 52.36 & 112.6 & 81.28 \\
\hline
\end{tabular}

Sumber: Direktori BI, diolah dan dikonfirmasi dengan LPP 
Secara umum, tentu suatu prestasi bagi industri karena keberhasilannya mendorong kenaikan output. Namun demikian, jika diamati secara seksama ada persoalan yang kontradiktif di mana penetapan output tinggi oleh bank hingga mengangkat ratio LDR secara rata-rata bukan dilakukan oleh bank di luar CR8 (kategori bank dengan penguasaan pangsa pasar sangat rendah). Sebagai contoh rentang LDR antara $28.96 \%-38.11 \%$ ditahun 2002 ditempati secara berturut-turut berdasar rating LDR terendah sampai tertinggi adalah: BII, Bank Lippo, Bank Permata, Bank Mandiri dan BNI. Peningkatan LDR secara perlahan hingga tahun 2008 mencapai rentang $54.65 \%-90.40 \%$. angka terendah dalam peran intermedisi ditempati oleh BCA yaitu $54.65 \%$, sementara LDR tertinggi adalah Bank Permata. Ini dapat diartikan bahwa bank berskala besar sangat lamban dalamekspansi kredit, sementara ekspansi kredit justru dilakukan oleh bank-bank di luar CR8.

Hubungan antara LDR dengan margin yang diperoleh bank, merupakan indikasi kedua, bahwa industri perbankan telah memanfaatkan market power adalah menetapkan harga tinggi dengan melakukan pembatasan kredit. Namun demikian, apakah benar perolehan margin yang besar oleh industri perbankan dapat disimpulkan sebagai tindakan monopolis (atau oligopolis) dalam penetapan harga secara kolusif masih membutuhkan bukti empiris yang lebih dapat dipertanggungjawabkan melalui pengujian conduct bank dalam hal ini digunakan pendekatan indeks learner.

Jika dikaji lebih mendalam, Tabel 4. melalui indikator indeks ratio konsentrasi, terjadi penurunan dari waktu-waktu meski dapat dikatakan sangat lambat. Sementara dari aspek perolehan margin bank, justru terjadi sebaliknya yakni ada kecenderungan kena- ikan. Menyimak pola hubungan seperti ini, secara kasat mata dapat dikatakan bahwa menurunnya derajat konsentrasi (derajat monopoli), justru mendorong kenaikan margin. Namun sekali lagi bahwa pernyataan ini hanya merupakan kesimpulan awal dari melihat hubungan data kecenderungan penguasaan pasar CR8 dengan tingkat margin industri. Ketika penyimpulan yang dinyatakan sebelumnya, maka pertanyaan secara teoritis lebih lanjut dapat diajukan yaitu: apakah pandangan neo klasik menjadi tidak berlaku bagi kasus industri perbankan di Indonesia. Jawaban ini tentunya tidak mudah, memperhatikan bahwa apakah penurunan derajat konsentrasi memang betul-betul signifikan, dan apakah hubungan yang bersifat terbalik ini telah memenuhi asumsi ceteris paribus sector perbankan seperti: ketiadaan skala ekonomi maupun informasi simetris.

Jika kondisi yang terakhir disebutkan terpenuhi maka hubungan negatif tersebut dapat diartikan bahwa pasar terkonsentrasi tidak sekaligus menunjuk kepada peluang adanya derajat monopoli tertentu dalam penetapan harga. Bank yang berada dalam tingkat konsentrasi rendahpun (penguasaan pasar yang kecil) dapat pula bertindak sebagai monopolis, mengingat bank tidak harus bersaing sempurna dalammeraih segmen pasar, masih banyak instrument lain yang dapat digunakan oleh bank untuk menetapkan harga tinggi terutama bagi bank kecil.

Seperti telah disinggung sebelumnya, menggunakan estimasi kasar derajat konsentrasi industri, derajat persaingan industri perbankan tidak menunjukkan perubahan berarti, yakni bertahan pada struktur oligopoly. Dugaan tersebut diperkuat dengan tingginya NIM yang diperoleh bank dari waktuwaktu, bahkan di saat masih menanggung BOPO tinggi. 
Kesimpulan yang bersifat sementara di atas, akan diujidengan penggunaan modal indeks learner.

Tahapan yang digunakan dalam penetapan model indeks learner sesuai formulasi yang telah diekspresikan dalam metodologi adalah membuat estimasi dualitas minimisasi biaya yang disajikan dalam hasil persamaan berikut:

$$
\begin{aligned}
& \mathrm{Ln} \mathrm{TC}=4,998487 *+0.764271^{*} \mathrm{Ln} \mathrm{W}_{1} \\
& \quad+0.161588^{*} \ln \mathrm{W}_{2}-0.251995 \ln \mathrm{W}_{3} \\
& \quad+1.275578 \ln \mathrm{Y}_{\ldots} . .(4) \\
& \mathrm{Se}(0.426207)(0.160422)(0.013522) \\
& \quad(0.08120)(0.21514)
\end{aligned}
$$

Pada persamaan 4. dapat dinyatakan bahwa keseluruhan koefisien regresi dualitas terbukti sangat meyakinkan menolak hipotesis null. Artinya, seluruh variabel bebas yang dimasukkan ke dalam model mampu menjelaskan perubahan variabel terikat, dalam hal ini biaya total yang dikeluarkan oleh industri perbankan.

Interpretasi estimasi TC pada persamaan di atas adalah biaya minimum yang dikeluarkan oleh bank dengan praktek terbaik. Setiap koefisien regresi menunjukkan elastisitas setiap harga input dan output. $\mathrm{W}_{1}$ mewakili variabel harga DPK diukur dengan nilai bunga yang dibayarkan bank per rupiah kredit sebesar 0.76. hal ini menunjukkan bahwa setiap kenaikan bunga $1 \%$ akan membawa dampak kepada kenaikan biaya, minimum $0.76 \%$. kenaikan $1 \%$ harga sumber daya manusia $\left(\mathrm{W}_{2}\right)$ bersifat inelastis, yakni hanya menaikkan biaya $0.16 \%$.

Perbedaan kenaikan biaya antara sumber penyebab kenaikan harga dana dengan SDM (labor) dapat dipahami, mengingat sumber pengeluaran utama bank yang memproduksi kredit berasal dari input dana DPK. Sementara labor lebih bersifat input pendu- kung bank dalam kerangka proses produksi output kredit.

Harga aktiva tetap yang diwakili oleh $\mathrm{W}_{3}$, menunjukkan arah yang kontradiktif. Suatu kenaikan $1 \%$ harga input, justru menurunkan biaya bank $0.25 \%$. Fakta empirik ini sangat realistis. Harga aktiva tetap, terkait dengan depresiasi yang harus dibebankan di sektor perbankan tidak selalu sama. Investasi yang mengandung teknologi, seiring dengan terus berkembangnya teknologi memerlukan penyesuaian waktu depresiasi yang lebih cepat dan bernilai tinggi. Akan tetapi pemanfaatan teknologi tinggi sangat mendukung bank dalam memberikan layanan prima kepada nasabah.

Pada akhirnya, bank-bank yang menanam investasi tetap yang cukup besar demi pengadaan peluasan jaringan kantor cabang, gedung-gedung yang representatif dan teknologi tinggi(ATM, internet banking, SMS banking dan lain-lain) akan semakin memperkokoh keberadaanya dalam industri. Tingginya kepercayaan masyarakat, kenyamanan, kemudahan dalam bertransaksi akan membawa manfaat bagibank dengan semakin luasnya segmen pasar yang diraih, memperoleh harga murah dalam mobilisasi dana dan pada akhirnya, penanaman aktiva tetap yang semula merupakan cost center dapat berubah menjadi profit center. Contoh: fasilitas layanan BCA menempatkannya sebagai bank transaksional, di mana semula investasi yang ditanam ke dalamATM telah dimanfaatkan bersama bank lain, dan pembebanan biaya administrasi kepada nasabah telah menjadikan investasi tersebut menumbuhkanfee based income bagi bank. Kemajuan teknologi selain akan memangkas biaya bank terutama dari aspek kemudahan menjangkau nasabah, juga memberikan beberapa manfaat di antaranya: kecepatan pemrosesan data berakurasi tinggi, transaksi online murah, 
bahkan dapat menggantikan beberapa pekerjaan yang semestinya dilaksanakan oleh SDM (Allen and Berger, 2003).

Koefisien terakhir yang patut dicermati adalah elastisitas output (Q). Kenaikan output kredit 15 telah mendorong industri perbankan menaikkan pengeluaran biaya di atas $1 \%$ atau tepatnya sebesar $1.2 \%$. besarnya koefisien ini memberikan petunjuk bahwa semakin besar kredit yang diberikan oleh bank justru mengeluarkan biaya semakin besar. Tingginya elastisitas ini dapat diduga erat kaitannya dengan buruknya kualitas pembiayaan oleh bank berskala besar dalam penyusunan portfolio kredit berskala besar.

Asumsi bank untuk menekan biaya dari pembentukan portfolio tersebut karena pertimbangan biaya realisasi dan pengelolaaan kredit yang relatif lebih murah dibanding harus mendistribusikan kredit yang bersakala kecil karena harus menyeleksi dan nasabah kredit yang sangat banyak. Namun, faktanya bank-bank kecil justru menanggung biaya lebih rendah dibanding bank berskala besar. Besarnya biaya ini diakibatkan oleh PPAP yang dicadangkan oleh bank-bank besar terkait penyaluran kredit yang sepenuhnya terserap dalam penyelesaian kredit bermasalah, karena kredit default justru dihadapi oleh bank-bank besar. Sementara bank-bank yang berorientasi kepada nasabah kecil (UMKM) terbukti mampu mengelola pembiayaan dengan kulaitas lebih baik.

Marginal cost menunjuk kepada pengertian seberapa besar biaya tambahan yang dikeluarkan bank pada saat menambah output kredit sebesar satu juta rupiah (satuan disesuaikan dengan input data awal).

Memperhatikan bahwa MC industrimerupakan derivasi fungsi persamaan biaya linier, sementara model dalam persamaan (1) adalah non linier. Untuk itulah derivasi lnTC terhadap $\operatorname{lnQ}$, koefisiennya masih bersifat elastisitas biaya, akan dikalikan dengan ratio $\mathrm{Tc}$ terhadap Q (rata-rata biaya kredit atau Average Cost). Berdasar hal tersebut, patut diperhatikan bagaimana posisiMC perusahaan dalam lingkup industri, baik untuk perusahaan yang tergabung dalam CR8 dan di luar CR8.

Tabel 4 menunjukkan bahwa biaya rata-rata kredit yang disalurkan bank-bank CR8 pada tahun 2002-2005 masih jauh lebih tinggi dibanding bank diluar kelompok CR8. Kondisi ini semakin memperkuat argumentasi sebelumnya, bahwa: pertama, bank berskala besar telah dihadapkan dengan banyaknya kredit berkualitas buruk terutama bagi portfolio kredit skala besar. Kedua, tingginya biaya per satu juta rupiah nilai kredit oleh kelompok CR8 merupakan dampak ikutan dari peningkatan upaya kehati-hatian bank dalam pemberian kredit. Sehingga langkah pem-

Tabel 4. Perkembangan Average dan Marginal Cost Industri Perbankan

\begin{tabular}{ccccc}
\hline Periode & \multicolumn{2}{c}{ Average Cost* $(=A C)$} & \multicolumn{2}{c}{ Marginal Cost ${ }^{*}(=M C)$} \\
& CR8 & Non CR8 & CR8 & Non CR8 \\
\hline 2002 & 0.2252 & 0.2018 & 0.2702 & 0.2422 \\
2003 & 0.2065 & 0.1901 & 0.2478 & 0.2281 \\
2004 & 0.1671 & 0.1587 & 0.2055 & 0.1904 \\
2005 & 0.1681 & 0.1488 & 0.2017 & 0.1786 \\
2006 & 0.1630 & 0.1710 & 0.1956 & 0.2052 \\
2007 & 0.1099 & 0.1405 & 0.1319 & 0.1686 \\
2008 & 0.1037 & 0.1274 & 0.1244 & 0.1528 \\
\hline
\end{tabular}

Sumber : Data Sekunder diolah

Keterangan $\quad$ : Data rata-rata biaya oleh setiap kelompok perusahaan 
batasan ini telah mendorong meningkatnya biaya sejalan meningkatnya pengeluaran biaya tetap (staff tetap, biaya modal dalam kerangka konsolidasi dan biaya upaya pemanfaatan teknologitinggi bidang perbankan). Sementara biaya variabel pembiayaan bunga dana pihak ketiga, dapat pula digolongkan sebagai biaya tetap memperhatikan bahwa bank harus mengeluarkan biaya bunga bagi pemilik tabungan. Ketiga, tingginya biaya yang harus dikeluarkan bank tanpa diimbangi dengan besarnya kredit yang disalurkan mendorong tingginya biaya rata-rata kredit per satu juta rupiah kredit. Namun, kondisi empat tahun pertama pengamatan berangsur-angsur membaik ditandai semakin menurunnya biaya rata-rata bahkan melampaui bank-bank di luar CR8.

Berbeda dengan bank kelompok CR8, bank non CR8 dengan konsentrasi pasar relatif rendah ini, mempunyai rata-rata biaya kredit lebih rendah pada periode 20022005. Hal ini disebabkan, pertama: bankbank kecil dipaksa untuk meraih omzet kredit yang relatif besar agar mampu memperoleh tingkat keuntungan tertentu. Peraihan omzet kredit, bagi bank kecil akan menjangkau Usaha Mikro Kecil dan Menengah (UMKM). Portofolio yang sangat menyebar kepada sejumlah UMKM akan dapat menekan resiko gagal bayar. Pembentukan portofolio ini terbukti mampu menekan resiko kredit macet atau bank-bank di luar CR8 memiliki NPL uang relatifterkendali. Kedua, kemampuan bank dalam kelompok CR8 tidak terlalu khawatir dengan upaya mengekspansi kredit. Ketiga, bank berskalakecil tidak banyak memperoleh kesempatan menderversifikasi aktiva produktivanya di luar kredit, atau bank dalam kelompok ini harus fokus kepada core bisnisnya dalam layanan utama yaitu alokasi aktiva produktif ke dalam kredit.
Sisi menarik dapat diamati, kelompok CR8 secara bertahap telah mampu menurunkan biaya rata-rata dari waktu ke waktu. Penurunan biaya dapat diindikasikan bahwa ada upaya-upaya bank berskala besar untuk mendorong peningkatan output kredit. Kedua, penurunan biaya rata-rata secara signifikan terjadi penurunan pada tahun $2007 \mathrm{ke}$ bawah (tahun 2007-2008). Penurunan biaya rata-rata juga terjadi pada bank non CR8, yaitu jika semula pada tahun 2002 sebesar $11 \%$ pada tahun-tahun berikutnya bertahan pada kisaran angka 8\%-9\%. Penurunan biaya ini telah jauh melampaui bank berskala kecil.

Memperhatikan bahwa $M C$ merupakan hasil perkalian elastisitas biaya dengan biaya rata-rata $A C$, di mana koefisien yang diperoleh dari persamaan regresi CobbDonglas bersifat konstan, maka dapat diperkirakan pencapaian $M C$ untuk kedua kelompok bank akan sejalan dengan capaian $A C$. Dapat diperhatikan kembali tabel 4. $M C$ linier searah dengan $A C$.

Kemampuankelompokbank diluarCR8 dalam menekan biaya rata-rata dengan asumsi ceteris paribus (misal harga output per satu juta rupiah nilai kredit adalah sama. Demikian pula bahwa output penghasil profit hanyalah kredit tanpa melibatkan output lain dan jasa-jasa lainnya), akan berdampak kepada daya saing bank lebih tinggi dibanding bank dalam kelompok CR8. Atau dengan kata lain, justru derajat monopoli tinggi akan dimiliki oleh bank berskala kecil dalam penentuan harga kreditnya.

Namun demikian, dalam perkembangannya fenomena menarik terjadi, di mana pada tahun 2006-2008 bank-bank berskala besar selain telah mampu menurunkan $A C$ dan $M C$ sekaligus telah melampaui capaian efisiensi biaya dari bank berskala kecil. 
Sepintas dapat diperhatikan pada Tabel 5, harga output yang dihasilkan bank secara bertahap mengalami penurunan untuk kedua kelompok bank. Memperhatikan bahwa harga output kredit relatif sulit diamati, karena data dalam laporan rugilabahanya mencantumkan pendapatan bunga tanpa pemilahan antara output kredit dengan aktiva produktif lainnya (sekuritas), maka harga output pengamatan mencerminkan rata-rata return yang diperoleh bank pada setiap satu juta rupiah kredit memungkinkan menghasilkan angka lebih besar dari semestinya. Namun demikian, angka tersebut justru akan menyiratkan arti yang lebih mendalam, yakni kepada keputusan bank dalam penetapan harga kredit maupun keputusan kepada alokasi DPK kepada sekuritas yang memberikan return dan tidak beresiko.

Secara keseluruhan, indikator penurunan biaya rata-rata telah dicerminkan dengan gerakan penurunan harga output oleh industri perbankan baik oleh kelompok CR8 maupun non CR8. Tingginya harga output yang melampaui harga kredit (biasanya hanya berada dalam kisaran rata-rata 9\%-20\%), mencerminkan bahwa angka tersebut adalah hasil dari alokasi bank kepada alokasi aktiva produktif non kredit.

Tahun 2002-2006, keengganan bank untuk menyalurkan kredit hingga biaya ratarata harus tinggi akan dapat tertutupi oleh bu- nga onlogasi. Hal ini diperkuat oleh laporan Bank Indonesia (2008) selama kurun waktu 2006-2008, ratipenempatan kredit masih berada dalam kisaran angka $50 \%$ untuk industri.

Dilihat daripenurunan harga output, mencerminkan bahwa telah ada kemauan bank untuk meningkatkan alokasi kredit dalam kerangka maksimisasi profit. Demikian pula, kemampuan bank CR8 yang menetapkan harga lebih tinggi dari bank non CR8 dengan selisih yang semakin mengecil, menunjukkan peran intermediasi dari bank-bank berskala besar telah mulai berjalan, bahkan menunjukkan tanda-tanda meningkatnya efisiensi biaya yang lebih besar.

Dilihat dari besarnya biaya marginal oleh industriperbankan di Indonesia, dapat disimpulkan kedua kelompok bank sangat tidak efisien. Namun demikian, tingginya harga tidak menyurutkan minat daridebitur dalam pengajuan kredit. Ini dapat diartikan potensi permintaan kredit relatif tinggi yang memberikan peluang bagi bank dalam menetapkan harga kredit tinggi.

Kuatnya pasar oleh industriperbankan menjadikannnya masih mampu meraih derajat monopoli tertentu, terbukti $A R$ sebagai indikator harga output masih berada di atas $M C$. Sepanjang kondisiini terus berlangsung dengan ketimpangan tinggi, dapat dikatakan industri perbankan telah melakukan eksploitasi terhadap pemilik sumberdaya khusus-

Tabel 5. Perkembangan Harga Output dan Indeks Learner Industri Perbankan

\begin{tabular}{ccccc}
\hline \multirow{2}{*}{ Periode } & \multicolumn{2}{c}{ Average Cost $*(=A C)$} & \multicolumn{2}{c}{ Marginal Cost $*(=M C)$} \\
& CR8 & Non CR8 & CR8 & Non CR8 \\
\hline 2002 & 0.3543 & 0.2972 & 0.3472 & 0.1851 \\
2003 & 0.3122 & 0.2765 & 0.2833 & 0.1750 \\
2004 & 0.2513 & 0.1982 & 0.2405 & 0.1055 \\
2005 & 0.2413 & 0.2772 & 0.1993 & 0.1021 \\
2006 & 0.2317 & 0.2213 & 0.1760 & 0.0728 \\
2007 & 0.1951 & 0.1842 & 0.3749 & 0.0862 \\
2008 & 0.1850 & 0.1681 & 0.3966 & 0.0910 \\
\hline
\end{tabular}

Sumber: Direktori Bank Indonesia, diolah 
nya kepada nasabah tanbungan ataupun kepada tenaga kerja. Kecuali, jika ketimpangan antara $M C$ dan $A R$ lebih disebabkan oleh teknologi, tidak akan terlalu menjadi persoalan. Demikian pula eksploitasi dapat terjadi kepada debitur. Sebagai contoh: industri perbankan akan elastis terhadap kenaikan harga kredit ketika tingkat bunga SBI yang menjadirujukan penetapan harga output oleh bank meningkat. Namin, kenaikan bunga kredit tidak secara otomatis menaikkan tingkat suku bunga tabungan. Sebaliknya, ketika suku bunga SBI menurun, hanya tingkat suku bunga tabungan yang seketika menurun, sementara tingkat bunga kredit masih tegar dengan tingginya bunga.

Perbandingan derajat persangan antara bank dalam CR8 dan non CR8, adalah derajat kuasa pasar bank berskala besar jauh lebih tinggi CR8 dibanding CR10. Bahkan dapat dikatakan, dalam perkembangan terakhir, bank-bank berskala kecil secara bertahap telah kehilangan derajat monopolinya dengan indikasi indeks Learner mendekati 0 . Sebaliknya bank berskala besar semakin mampu menikmati derajat monopoli tertentu.

Semakin mengecilnya indeks Learner oleh bank berskala kecil disebabkan oleh dua hal. Pertama, meski bank mampu secara bertahap menurunkan biaya rata-rata, namun di waktu tertentu masih menghadapi kenaikan biaya rata-rata kembali. Hal ini disebabkan langkah ekspansif oleh bank berskala kecil telah menaikkan kredit berkualitas buruk yang pada gilirannya menaikkan PPAP atau mendorong kenaikan AC. Kedua, karakteristik bank berskala kecil untuk meraih captive market dengan derajat kuasa pasar melalui penetapan harga lebih tinggi (dengan memperhatikan resiko yang lebih tinggi), mulai direbut oleh bank berskala besar. Persaingan untuk meraih pangsa pasar yang sama ini, telah mendorong turunnya harga kredit sec- tor usaha menengahdankecil. Akibatnya, bank berskala kecil yang lebih mengandalkan core bisnis pada kredit harus tertekan pendapatannya, sementara aktiva produktif lainnya tidak dapat tumbuh sebagaimana bank berskala besar.

Derajat monopoli(meskitidak sempurna) oleh bank berskala besar lebih disebabkan oleh upayanya dalam membatasi kredit, namun mengalihkan kepada aktiva produktif non kredit pada 3 tahun pertama pengamatan. Langkah konsolidasi belum membuahkan hasil kepada capaian efisiensi. Pada tahun berikutnya derajat monopoli diraih dengan semakin menurunnya $M C$. Dapat dikatakan, bank berskala besar telah meraih dua manfaat sekaligus dalamkerangkan pencapaian derajat monopolinya, yaitu: meningkatnya efisiensi biaya akibat konsolidasi (terutama pada dua tahun terakhir) dan mampu menetapkan harga output relatif tinggi, akibat peluang portofolio aktiva produktif yang lebih beragam.

Bank berskala kecil, mendekati derajat persaingan sempurna dalam arti mereka tidak akan mampu mengendalikan harga di luar industri. Mereka hanya sebagaipengambilharga di pasar. Upaya meningkatkan daya saing tidak terlepas bagaimana bank akan mampu meningkatkan efisiensibiayanya, yang tampaknya relatif sulit tanpa diimbangi oleh kapasitas permodalan yang kuat sebagaimana langkah yang ditempuh oleh bank dalamkelompok CR8. Kedua derajat monopoli masih dapat diperoleh jika dalam perolehan kredit, bank-bank mampu meningkatkan pangsa pasar baru terutama nasabah kredit yang masih baru berhubungan dengan bank, sehingga dari beberapa aspek masih memungkinkan menetapkan harga relatif tinggi dengan memperhatikan beban resikonya. Namunlangkah ini tentu tidak akan dapat bertahan lama, ketikanasabah yang bersangkutan sudahbank- 
able. Persaingan meraih segmen pasar dengan kualitas nasabah yang baik akan kembali terjadi sehingga pada akhirnya excess profitsecara perlahan akan menyusut.

\section{Penutup}

Penelitian ini berupaya untuk mengamati bagaimana perkembangan derajat persaingan industri perbankan di Indonesia pada periode pengamatan 2002-2008 dengan menggunakan indeks Learner. Pengelompokkan industri ke dalam kelompok CR8 dan non CR8 menyimpulkan bahwa bank CR8 yang identik dengan bank berskala besar mempunyai derajat persaingan yang relatif rendah (mempunyai derajat monopoli lebih tinggi) dibanding bank dalam kelompok non CR8.

Kelebihan dari indeks Learner dalam mengukur derajat persaingan dibanding ratio konsentrasiadalah mampu mengukur perilaku bank secara langsung dalam penentuan harga (pricing). Derajat monopoli yang dimiliki industriperbankan menunjukkan adanya kuasa pasar di mana bank yang berskala besar, meski menghadapi biaya marginal yang tinggi, namun masih mampu menetapkan harga output diatas $M C$.

Konsolidasi yang terjadi mulai menunjukkan kinerjanya terutama dalam mendorong efisiensi dengan indikator menurunnya $A C$ dan $M C$. Bank berskala kecil dalam posisi sebagai pengambil harga di pasar harus mengambil langkah yang sama seperti halnya bank yang berada dalam kelompokCR8.

Dugaan bahwa bank berskala besar selalu memanfaatkan kuasa pasarnya dalam menetapkan harga sebagaimana pandangan neo klasik belum sepenuhnya dapat dibuktikan. Setidaknya bukti empiris telah diberikan oleh bank berskala besar. Penurunan biaya secara bertahap (dengan indikator menurunnya $A C$ dan $M C$ ), telah menguatkan de- rajat monopolinya. Namun demikian diperlukan kembaliupaya-upayaregulasiyang mendorong persaingan antar bank-bank besar, sehingga tindakan kolusif tersembunyi dengan tegarnya harga kredit yang tinggidan harga elastis menurun suku bunga.

Penelitian ini memiliki beberapa keterbatasan. Pertama, model estimasi fungsi biaya Cobb-Donglas hanya menghasilkan elastisitas konstan selama periode pengamatan, sehingga penaksiran $M C$ dari waktu ke waktu mengandung kelemahan yang dapat disempurnakan melalui model estimasi translog. Pemenuhan model tersebut menghendakijumlah sampel yang relatif besar karena adanya variabel penjelas yang bersifat multiplikatif. Pembentukan model juga belum melibatkan variabel eksternal di luar input-output.

Keterbatasan kedua, analisis sumber terjadinya derajat monopoli hanya dianalisis secara deskriptif, dan belum melibatkan suatu pengujian yang kompleks seperti apakah derajat monopoli yang besar lebih disebabkan penetapan harga yang tinggi atau karena secara signifikan bank menghadapi penurunan $M C$. Demikian pula diperlukan memperluas kajian yang memberikan penjelasan tingginya kuasa pasar sektor perbankan. Dari aspek regulasi diperlukan informasi yang mendukung tentang seberapa derajat persaingan industri yang tetap menjamin stabilitas industri perbankan.

\section{DAFTAR PUSTAKA}

Aigner, D.J., Lovell C.A.K and P.Schmidt. 1977. Formulation and Estimation of Stochastic Frontier Production Function Models. Journal of Econometrics, Vol 6, pp. 21-37.

Athoillah. 2010. Struktur Pasar Industri Perbankan di Indonesia. Journal of 
Dinamika Derajat Persaingan Industri Perbankan Indonesia (Idah Zuhroh)

Indonesian Applied Economics. Vol4, No,1 pp. 1-10.

Bain, J.S. 1951. Relation of Profit Rate to Industry Concentration. Quarterly Journal of Economics. Vol 65, pp. 293-234.

Berger, A.N., Klapper, L.F. and Turk- Ariss, R. 2009. Bank Competition and Financial Stability. Journal of Financial Services Research, Vol. 35 No. 2 pp. 99-118.

Casu, B and Girardone, C. 2006. Bank Competition, Concentration and Efficiency in the Single European Market. Manchester School, Vol 74 No.4 pp. 441-468.

Claessen, S, Luc Laeven. 2004. What Drives Bank Competition: Some International Evidence. Journal of Money Credit and Banking. Vol.36. pp 563-584.

Coelli, T.J. 1996a. A Guide to Frontier Version 4.1: A Computer Program for Frontier Production Function Estimation. CEPA Working Paper. July.

De Rozas, Luis Guitterrez. 2007. Testing for the Competition in the Spanish Banking Industry: the Panzar -Rosse Approach Revisited. The Working $\mathrm{Pa}$ per Series, Banko de Espana.Madrid.

Eisenbeis, A.Robert, G.D Ferrier and S.Kwan, 1999. The Informativeness of Stochastic Frontier and Programming Frontier Efficiency Scores Cost Efficiency and Other Measures of Bank Holding Company Performance. USA: Federal Reserve Bank of 'Atlanta Working Paper, December: 99-23'

Elzinga K.G., and David E. Mills. 2012. Learner Index of Monopoly Power: Origin and Uses -American. Avalaible online at: $h$ htp//www.aeweb.org/aeal ..../retrieve.php? (accessed January 2013).

Gujarati, Damodar N. 2003. Basic Econometrics. Mc-Graw Hill. New York.

Iveta, Repkova. 2012. Market Power in the Czech Banking Sector. Journal of Competitiveness. Vol 4. No 1, pp.143-155.

Keeley, M. 1990. Deposit insurance, Risk and Market Power in Banking. American Economic Review vol 80 No.5 pp. $1183-1200$.

Marcus, A.J. 1984. Deregulation and Bank Financial Policy. Journal of Banking and Finance Vol.8 No.4.pp. 557-565.

Nachrowi, D.N dan Hardius Usman. 2006. Pendekatan Populer dan Praktis Ekonometrika untuk Analisis Ekonomi dan Keuangan. Lembaga Penerbit Fakutas Ekonomi Universitas Indonesia.

Buletin Ekonomi Moneter dan Perbankan. Tersedia on line pada: Http:// www.bi.go.id/id/publikasi/jurnal (Diakses Maret 2014).

Raul Osvaldo Fernandez and Jesus G-Garza -Garcia. 2010. The Relationship between Bank Competition and Financial Stability of The Mexican Banking. Avalaible on line at Hhtp:// www.iese.edu/research/pdfs/D1 0852-E.pdf (accessed June 2013).

Sanya, S and Matthew Gaertner. 2012. Assesing Bank Competition within the East African Community. IMF Working Paper WP/12/32

Sealey, C.W and Lindley, J.T. 1977. Inputs, Outputs, and a Theory of Production and Cost at a Depository Financial Institutions. Journal of Finance. Vol 32 No.4 pp.1251-1266. 
